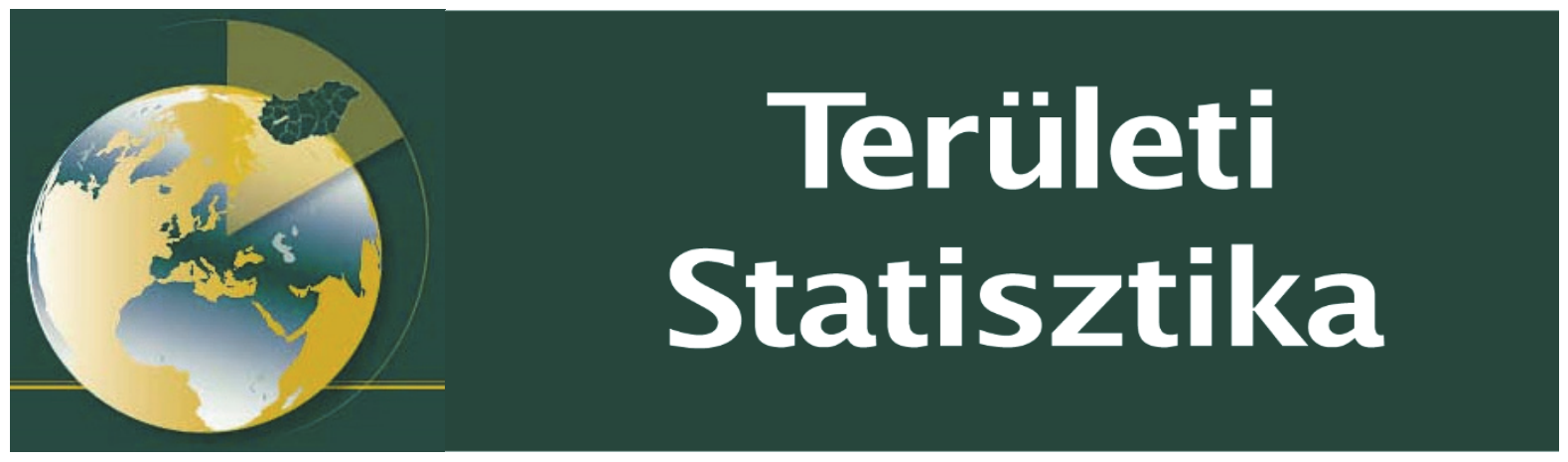

Közzététel: 2021. január 19.

A tanulmány címe:

Az ázsiai közvetlentőke-befektetések sajátosságai a visegrádi országokban: a beruházási stratégiák és a termelékenység összefüggései

Szerzők:

Gál Zoltán-Fazekeas Gábor

https://doi.org/10.15196/TS610105

Az alábbi feltételek érvényesek minden, a Központi Statisztikai Hivatal (a továbbiakban: KSH) Területi Statisztika c. folyóiratában (a továbbiakban: Folyóitat) megjelenó tanulmányra. Felhasználó a tanulmány, vagy annak részei felhasználásával egyidejüleg tudomásul veszi a jelen dokumentumban foglalt felhasználási feltételeket, és azokat magára nézve kötelezónek fogadja el. Tudomásul veszi, hogy a jelen feltételek megszegéséböl eredö valamennyi kárért felelösséggel tartozik.

1) A jogszabályi tartalom kivételével a tanulmányok a szerzői jogról szóló 1999. évi LXXVI. törvény (Szjt.) szerint szerzői műnek minősülnek. A szerzői jog jogosultja a KSH.

2) A KSH földrajzi és időbeli korlátozás nélküli, nem kizárólagos, nem átadható, térítésmentes felhasználási jogot biztosít a Felhasználó részére a tanulmány vonatkozásában.

3) A felhasználási jog keretében a Felhasználó jogosult a tanulmány:

a) oktatási és kutatási célú felhasználására (nyilvánosságra hozatalára és továbbítására a

4. pontban foglalt kivétellel) a Folyóirat és a szerző(k) feltüntetésével;

b) tartalmáról összefoglaló készítésére az írott és az elektronikus médiában a Folyóirat

és a szerző $(\mathrm{k})$ feltüntetésével;

c) részletének idézésére - az átvevő mú jellege és célja által indokolt terjedelemben és az eredetihez híven - a forrás, valamint az ott megjelölt szerző(k) megnevezésével.

4) A Felhasználó nem jogosult a tanulmány továbbértékesítésére, haszonszerzési célú felhasználására. Ez a korlátozás nem érinti a tanulmány felhasználásával elóállított, de az Szit. szerint önálló szerzői műnek minősülő mú ilyen célú felhasználását.

5) A tanulmány átdolgozása, újra publikálása tilos.

6) A 3. a)-c.) pontban foglaltak alapján a Folyóiratot és a szerző(ke)t az alábbiak szerint kell feltüntetni:

„Forrás: Területi Statisztika c. folyóirat 61. évfolyam 1. squámában megjelent, Gál Zoltán - Faz̨ekas Gábor által irt, Az ázsiai közvetlentőke-befektetések sajátosságai a visegrádi országokban: a beruházási stratégiák és a termelékenység összefüggései $c$. tanulmány"

7) A Folyóiratban megjelenő tanulmányok kutatói véleményeket tükröznek, amelyek nem esnek szükségképpen egybe a KSH, vagy a szerzők által képviselt intézmények hivatalos álláspontjával. 


\title{
Az ázsiai közvetlentöke-befektetések sajátosságai a visegrádi országokban: a beruházási stratégiák és a termelékenység összefüggései
}

\section{Asian Foreign Direct Investment (FDI) in the Visegrad Countries: Relationships between investment strategies and labour productivity}

\author{
Gál, Zoltán A tanulmány célja az ázsiai (kínai, japán és \\ Pécsi Tudományegyetem \\ dél-koreai) külföldi közvetlentőke- \\ Közgazdaságtudományi Kar; \\ Közgazdaság- és \\ Regionális Kutató Központ \\ E-mail: galz@ktk.pte.hu \\ Fazekas, Gábor \\ Pécsi Tudományegyetem \\ Közgazdaságtudományi Kar \\ Regionális Politika és Gazdaságtan \\ Doktori Iskola \\ E-mail: fagabor@freemail.hu \\ Kulcsszavak: \\ Kína, \\ Japán, \\ Dél-Korea, \\ visegrádi oszágok, \\ külföldi közvetlentőke-befektetések \\ (FDI), \\ munkatermelékenység \\ befektetések (FDI) motivációinak feltárása a \\ visegrádi országokban. A kutatás arra a kér- \\ désre keresi a választ, hogy az ázsiai FDI \\ mennyire függ a célországok termelékenységi \\ mutatóinak alakulásától. A termelékenység \\ stratégiai szempontból egyre fontosabb be- \\ fektetési tényezőnek számít a hozzáadott ér- \\ ték szempontjából. Az egyes célországok \\ termelékenysége között kialakult jelentős elté- \\ rések hosszú távon befolyásolhatják a további \\ tőkebeáramlást. A korrelációanalízis és a \\ Granger-okság teszteredményei rámutattak a \\ célországok (visegrádi országok) termelékeny- \\ ségének alakulása és a három ázsiai ország \\ befektetési volumene közötti összefüggések- \\ re. A szerzők empirikus vizsgálati eredményei \\ szerint mindhárom ázsiai ország vállalati be- \\ fektetéseinél meghatározó befektetői szem- \\ pont a munkatermelékenység szintje. Míg a \\ japán és a dél-koreai befektetések pozitívan \\ hatottak a visegrádi országok termelékenységi \\ szintjére, addig a kínai közvetlentőke- \\ befektetéseket a célországok magasabb ter- \\ melékenységi mutatói vonzották.
}


The aim of the study is to explore the Asian FDI motivations (those of China, Japan and South Korea) in the Visegrad countries. The research seeks answers about the extent of the dependency of the Asian investments on the productivity indicators of the destination countries. Productivity is considered an important factor in terms of added value, therefore its strategic management is of paramount importance. Regarding productivity, significant differences have been detected between individual destination countries over the past decade which may influence further influx of FDI in the long run. The correlation analysis and the Granger causality test showed that in the vast majority of cases there are correlations between productivity of the Visegrad Group states and the volume of investments of the three Asian countries. Results have shown that the level

Keywords: of labour productivity is a key consideration China, for FDI by all three Asian investor countries.

Japan, Japanese and South Korean investments have

South Korea, a positive effect on the productivity levels of Visegrad Countries, the host CEE countries, while Chinese FDI is

FDI stock, driven by the higher productivity indicators labor productivity of the host countries.

Bekïldve: 2020. június 3.

Elfogadva: 2020. szeptember 4.

\section{Bevezetés}

Az ázsiai tőkebefektetések jelentős mértékben megnövekedtek a világgazdaságban, s ezek meghatározó célpontja Európa és kisebb mértékben a visegrádi országok (Goreczky 2017). A rendszerváltás óta eltelt idôszakban a visegrádi országok gazdaságpolitikájának egyik kiemelt célja a külföldi közvetlentőke-befektetések (foreign direct investment - FDI) vonzásának támogatása.

Az FDI kiemelkedő jelentőségű a kelet-közép-európai régióban, így Magyarországon is. Az FDI az utóbbi 25-30 évben jelentős mértékben nőtt a régió minden országában és a tôkeáramlások legfontosabb eszköztípusává vált, alapvetően segítve ezen országokat a régió (külföldibefektetés-vezérelt) fejlődési pályáinak alakításában

Területi Statisztika, 2021, 61(1): 105-130; DOI: 10.15196/TS610105 
(Gál 2019). Az FDI szerepe jelentős volt a privatizációban és az átalakulás első szakaszában a legfontosabb tőkebefektetési formát jelentette (Kalotay 2010). Az FDI felgyorsította a privatizációt, és így hozzájárult az állami tulajdon lebontásához, támogatta a szerkezetváltást és a piacgazdaság megteremtését, ugyanakkor egyes ágazatokban a külföldi tulajdon dominánssá válásához is vezetett, ami tovább növelte a régió FDI-vonzerejét (Gál-Schmidt 2017).

A régió relatív gazdasági fejlettsége és a nyugat-európai befektetőkhöz való közelsége miatt vonzóvá vált a külföldi közvetlentőke-befektetők számára, ahová elsősorban a fejlett nyugati államokból, mindenekelőtt az Európai Unióból (EU) áramlott be az FDI. A 2008. évi válság jelentette fordulópont erôsítette az ázsiai befektetők érdeklődését az EU és szűkebben a kelet-közép-európai régió iránt (Varga 2018), illetve a régió országai is igyekeztek az egyoldalú nyugat-európai tőkefüggőségüket diverzifikálni, és azt az ázsiai, mindenekelőtt az expanzív kínai befektetők révén kielégíteni. A japán és a dél-koreai tőke korábban sem volt ismeretlen a régióban, azonban a kínai beruházások csak a válságot követően számítanak egyre jelentősebbeknek. Vizsgálatunk tárgyát nemcsak a tőkebefektetések származási helye és annak földrajzi megoszlása képezi, de a célországok befektetést vonzó telepítőtényezóinek, illetve a befektető külföldi vállalatok telephelyválasztó stratégiáinak bemutatása is.

A tanulmány arra a kérdésre keresi a választ, hogy az ázsiai befektetóket mennyire motiválják a célországokban meglévő termelékenységi teljesítmények. A munkatermelékenység egyre fontosabb stratégiai befektetési tényező a hozzáadott érték szempontjából. A célországok között jelentôs eltérések alakultak ki az elmúlt évtizedben, melyek hosszú távon befolyásolhatják a jövőbeni tőkebeáramlást. Korrelációanalízissel és Granger-okság teszttel tárjuk fel a visegrádi országok munkatermelékenységi mutatói és a három ázsiai ország befektetései közötti összefüggéseket. Vizsgálatunk középpontjába helyezzük továbbá a fejlett és a feltörekvő ázsiai befektetők telephelyválasztási stratégiáiban megfigyelhető eltéréseket is, és ennek kapcsán elemezzük a térségbe érkező kínai tőke specifikus, a másik két országétól eltérô motivációit is.

A tanulmány fejezetei az FDI stratégiai és a feltörekvő ázsiai országok multinacionális vállalatainak befektetési motivációit, majd az ázsiai befektetők hatékonyságkereső stratégiáinak érvényesülését vizsgálják az EU-ban és a visegrádi országokban. Az empirikus elemzés az ázsiai befektetők hatékonyságkereső preferenciái és a munkatermelékenység közötti összefüggéseket mutatja be a visegrádi országokban.

\section{Az FDI jelentösége a befektetö és a célországok szempontjából}

A vállalatok nemzetköziesedésének korai elméletei jórészt makroszempontúak, nemzetgazdasági megközelítésúek voltak. Ide tartozik a komparatív előnyöket, az országok tényezőellátottságát kiemelő neoklasszikus alapokon álló HeckscherOhlin-modell. A tőke áramlásában utóbbi modell a fejlett (tőkegazdag) észak és a

Területi Statisztika, 2021, 61(1): 105-130; DOI: 10.15196/TS610105 
fejletlen (tőkeszegény) dél befektetési relációt vette csak figyelembe, az FDI meghatározó része azonban az elmúlt évtizedekben döntően a fejlett régiókon belül mozgott (Lucas 1990).

Az ezredfordulót, illetve a 2008. évi válságot követően ugyanakkor a feltörekvő országok külföldi közvetlentőke-befektetőként való megjelenése új földrajzi irányokat jelölt ki a nemzetközi tőkeáramlás folyamatában (Kalotay 2004, Gál-Juhász 2016).

Míg az 1980-as éveket megelőzően a multinacionális vállalatok az áruexportra helyezték a hangsúlyt, addig a globalizáció kiteljesedésével, az 1980-as évektől ${ }^{1}$ a tulajdonszerzéssel járó FDI vált nemzetközi terjeszkedésük kulcselemévé. E vállalatok hosszabb távon nem tarthatják fenn nemzetközi piaci részesedéseiket külföldi termelés, tehát FDI nélkül (Blomström-Kokko 1998). Az FDI csúcsidőszaka az ezredfordulóra tehető (ekkor arányuk már a nemzetközi tőkeáramlás 40\%-át tette ki). A fejlődő országokba irányuló külföldi tőkebefektetéseken belüli részesedése 2005ben elérte az összes FDI-beáramlás 63\%-át (Gál 2010). Ennek jelentős hányada a kelet-közép-európai országokba és Kínába áramlott (Gál-Juhász 2016).

A közvetlentőke-befektetések során felhalmozott FDI-állomány 2007-ben negyede volt a világ GDP-jének, és közel megegyezett az áru- és szolgáltatásexport értékével. A bruttóállóeszköz-beruházásoknak világszinten 1990 és 2003 között mintegy 8\%-át adták az FDI-k, tehát a beruházásokban továbbra is a hazai tőke maradt a meghatározó. Ugyanakkor a fejlődő és a feltörekvő országokban a külföldi közvetlen tőke részesedése a teljes hazai beruházásokon belül elérte a világátlag kétszeresét. A kelet-közép-európai országokban az FDI részesedése a bruttóállóeszköz-beruházásokból ennél is nagyobb, 25-27\%-os volt a 2000-es évek közepén (Gál 2010, Gál-Juhász 2016).

Az FDI-vel megvalósított külföldi tulajdonszerzés, a földrajzi hely és a nemzetköziesedés elônyeinek kiaknázásával a munkaerőköltség és a vállalati transzferek sokkal olcsóbbá váltak, mint a hagyományos export. Stratégiai elónyeit (lásd Dunning [1988] tulajdonosi-elhelyezkedési-nemzetköziesedési előnyökre vonatkozó [ownership-location-internalization - OLI-] paradigmáját) a befektető külföldi vállalatok igyekeztek kiaknázni. A multinacionális vállalatok az FDI-vel megszerzett leányvállalataik nemzetközi hálózatát versenyelőnyökhöz jutásra és piaci pozíciójuk megerősítésére használták fel. ${ }^{2}$

A multinacionális vállalatok külföldi befektetéseinek motiváció-rendszerét Dunning (1992) négy csoportra osztotta: piacszerző", hatékenyságkeresó, stratégiaielónysžrző és eröforrás-keresó befektetéselere. A beruházási döntés ugyanakkor általában komplex, azt többféle motiváció is befolyásolja. A Kelet-Közép-Európába érkező tőkebe-

${ }^{1}$ Az 1980-as évek nagy bankválságai hatására a banki kölcsönök visszaszorulásával az FDI - az 1990-es évek után - ismét dominánssá vált.

2 Az 1990-es években az FDI-n belül a határokon átívelő vállalat-összeolvadások és -felvásárlások 1994-ben az összes FDI felét, 1999-ben pedig már 83\%-át adták, ami 2004-re 58\%-ra mérséklődött (Csáki 2006).

Területi Statisztika, 2021, 61(1): 105-130; DOI: 10.15196/TS610105 
fektetők esetében, csakúgy mint a régió később külföldi befektetővé váló vállalatai esetében is a piacszerző stratégia volt a legfőbb kezdeti motiváció, ami a vállalat külföldi terjeszkedésével kiváltja az exportot, illetve helyi piacot szerez leányvállalata termékeinek. Az ehhez kapcsolódó befektetési stratégiát nevezzük horizontálisnak. A hatékonyságkereső vertikális stratégia a vállalatok a tényezőellátottságában és az azok áraiban (munkabérekben) mutatkozó különbségek kiaknázását célozza. Ekkor a vállalati értéklánc egyes elemeit különböző országokban múködő telephelyekre telepítik. Ezt a célt szolgálja a munkaerőigényes ágazatok áthelyezése is az alacsony munkaerőköltségű, kevéssé fejlett, illetve fejlődő országokba, ugyanakkor az egyes tudásintenzív, magasabb szakképzettséget igénylő ágazatokat (például üzleti szolgáltatások) a földrajzilag közelebb fekvő, de relatíve alacsonyabb bérköltségú országokba (például Kelet-Közép-Európa) telepítik (Dunning-Lundan 2008). A stratégiai előnyök megszerzése a vállalati versenyképességet javító külföldi befektetések révén valósul meg. Ide tartoznak például a vállalatfelvásárlások és fúziók révén elérhető előnyök. Az erőforrás-kereső stratégia a természeti és az emberi erőforrások, valamint a szellemi tôke és a technológiai eredmények megszerzését jelenti (DunningLundan 2008). Az erőforrás-kereső stratégia meghatározó szerepet játszik a kínai vállalatok befektetéseiben és vállalatfelvásárlásaiban.

A FDI-vezérelt fejlődés azonban a félperifériákra jellemző függő piacgazdasági modell kialakulásához, illetve a külső tőke, a technológia- és piacfüggőség állandósulásához vezetett (Nölke-Vliegenthart 2009, Gál-Schmidt 2017). Annak ellenére, hogy a külföldi terjeszkedés stratégiai előnyeit (lásd Dunning OLI-paradigmáját [1988]) a befektető külföldi vállalatok kiaknázták, és leányvállalataik versenyképessége növekedett, de a befektetések kisugárzó hatása - többek között a hazai vállalatokkal kialakított kapcsolatok, különösen a magasabb hozzáadott értékú területeken (például $\mathrm{K}+\mathrm{F}$ ) - kiaknázatlan maradt (Narula-Guimón 2010). A túlzott FDIfüggőség miatt mind az ágazati szerkezet javításának, mind pedig a termelékenység növelésének lehetőségei hosszú távon is korlátozottak. Az FDI-vezérelt fejlődési modell azonban a nyugat-európai EU-tagországok befektetői dominanciáját hozta magával, ami jelentősen hozzákapcsolta a kelet-közép-európai országokat az EU, s azon belül is Németország gazdasági ciklusaihoz, s így jelentős szektorális (autóipar) függőséghez is vezetett.

A 2008/2009. évi globális pénzügyi válság és az azt követő eurózónabeli adósságválság után a fejlett országok globális részaránya az FDI-befektetéseket és -kifektetéseket tekintve is csökkent. A fejlődő-feltörekvő országokból - mindenekelőtt Ázsiából - származó FDI azonban tovább növekedett, így 2014-ben és 2018-ban a fejlődő országokba több FDI érkezett, mint a fejlett régiókba. A fejlődő-feltörekvő országok mint tőkebefektetők is felzárkóztak, köztük a visegrádi országok multinacionális befektetői is (Sass-Vlčková 2019). Míg 2009-ben az FDI-nek csak 20, addig 2018-ban már több mint a 40\%-át tették ki, megközelítve ezzel a fejlett országok szintjét.

Területi Statisztika, 2021, 61(1): 105-130; DOI: 10.15196/TS610105 
A visegrádi országokba az Egyesült Államok után az ázsiai országokból JJapán, Dél-Korea) érkezett a legtöbb FDI. Az ázsiai országok közül Japán, India és Kína befektetéseiket közvetítő országokon keresztül valósítják meg, ezért a közvetlen és a végső befektetők szerinti statisztikákban nagyságrendi (országonként eltérő, de minimum kétszeres) különbségek figyelhetők meg (Varga 2018, Sass et al. 2019). A közvetlen befektető szerinti ún. közvetítő országok jellemzően offshore központok (Hollandia, Luxemburg, Ciprus, Hongkong). Varga (2018) vizsgálataiban a kínai tőke nem jelent meg 2014-ben a legnagyobb befektetók között, aminek az az oka, hogy a kínai befektetések is jellemzően közvetítő országon keresztül érkeznek a régióba. Sass és szerzőtársai (2019) kimutatták, hogy az ázsiai befektetők, köztük a kínaiak, gyakran közvetítő országokon keresztül fektetnek be a régióban. Magyarország esetében a közvetlen és a végső befektető országok szerint számolt kínai FDIállomány között hatszoros eltérés volt 2016-ban.

\section{A feltörekvő ázsiai országok befektetési motivációi}

Az ázsiai tőkekihelyezések expanziója az 1990-es évek elejének ázsiai (japán és délkoreai) befektetői boomját követően 2008 után gyorsult fel és töretlenül folytatódott 2017-2018-ig. Ebben a folyamatban mindenekelőtt a „kínai tényező” volt a fő mozgatórugója a fejlődő-feltörekvő országokból, azon belül is elsősorban az ázsiai régióból származó FDI-nek. Kína vált az Egyesült Államok és Japán mellett az egyik legnagyobb FDI-kifektető országgá (globális szinten a tôkeexport [outward foreign direct investment - OFDI] egyharmada Kínából érkezett 2018-ban). Ez az arány az azt megelőző években még ennél is nagyobb volt. Ugyanakkor Kína részesedése az FDI-ben már évek óta 20\%-os szinten van (UNCTAD 2018). ${ }^{3}$ Számos tanulmány rámutatott arra, hogy a feltörekvő ázsiai országok tôkebefektetési expanziója egészen 2017-ig folytatódott. A Kína és az Egyesült Államok közötti kereskedelmi háború azonban hozzájárult az FDI mérséklődéséhez, nemcsak a fejlett-feltörekvő országok relációjában, de csökkentek - a protekcionista kereskedelmi és befektetési politikát hirdető amerikai „Trump-faktor” következtében - a fejlett országok közötti befektetések is (ezt a csökkenő trendet a COVID-járvány jelentősen felerôsítheti). A tőkebőség és annak alacsonyabb fajlagos költsége miatt az ázsiai befektetők kihívást jelentenek a fejlett gazdaságok hagyományos cégei számára is (Santiso 2007).

A szakirodalom és a statisztikák áttekintése arra adott választ, hogy Kína, Japán és Dél-Korea egyaránt növelte tőkekihelyezéseit a világban (UNCTAD 2018). A befektetett tőke nagyságát tekintve is az előbbi országsorrend adódik. A visegrádi országokban az 1990-es évek elején megjelent japán FDI aránya mintegy 50\%-os volt a három ázsiai befektető ország együttes állományán belül, ezt követte DélKorea 29 és Kína (Hongkonggal együtt) 21\%-os részesedéssel. A célországot tekint-

${ }^{3}$ A 2018. évi UNCTAD-statisztikákban Hollandia mint tipikus közvetítője - többek között - az ázsiai FDI-nek is, a közvetlentőke-kifektetések tekintetében globálisan a 3. helyre került, megelőzve Kínát.

Területi Statisztika, 2021, 61(1): 105-130; DOI: 10.15196/TS610105 
ve a japán befektetők részesedése Lengyelországban, a dél-koreaiaké Csehországban, a kínai befektetőké pedig Magyarországon a legnagyobb (Sass et al. 2019).

1. táblázat

A visegrádi országokba érkező ázsiai közvetlentőke-befektetés állománya és megoszlása, a közvetlen befektetők számbavétele alapján, 2018

Stock and distribution of Asian foreign direct investment arriving to the Visegrád countries based on the review of the direct investors, 2018

\begin{tabular}{l|c|c|c|c|c|c}
\hline \multirow{2}{*}{$\begin{array}{c}\text { Célország/ } \\
\text { célországcsoport }\end{array}$} & \multicolumn{2}{|c|}{ Dél-Korea } & \multicolumn{2}{c|}{ Japán } & \multicolumn{2}{c}{ Kína } \\
\cline { 2 - 7 } & $\begin{array}{c}\text { állomány, } \\
\text { millió euró }\end{array}$ & $\begin{array}{c}\text { megoszlás, } \\
\%\end{array}$ & $\begin{array}{c}\text { állomány, } \\
\text { millió euró }\end{array}$ & $\begin{array}{c}\text { megoszlás, } \\
\%\end{array}$ & $\begin{array}{c}\text { állomány, } \\
\text { millió euró }\end{array}$ & $\begin{array}{c}\text { megoszlás, } \\
\%\end{array}$ \\
\hline Csehország & 2990 & 11,0 & 1759 & 0,6 & 607 & 1,0 \\
Lengyelország & 979 & 3,6 & 836 & 0,3 & 260 & 0,4 \\
Magyarország & 2469 & 8,5 & 1136 & 0,5 & 133 & 0,2 \\
Szlovákia & 2956 & 10,9 & 126 & 0,0 & 31 & 0,0 \\
Visegrádi országok & $\mathbf{9 3 9 4}$ & $\mathbf{3 4 , 0}$ & $\mathbf{3 8 5 7}$ & $\mathbf{1 , 4}$ & $\mathbf{1 0 3 1}$ & $\mathbf{1 , 5}$ \\
EU-28 & $\mathbf{2 7 1 5 3}$ & $\mathbf{1 0 0 , 0}$ & $\mathbf{2 9 5} \mathbf{3 3 7}$ & $\mathbf{1 0 0 , 0}$ & $\mathbf{6 3 0 4 0}$ & $\mathbf{1 0 0 , 0}$
\end{tabular}

Forrás: Eurostat, National Bank of Poland, National Bank of Slovakia, National Bank of Czech Republic és a Magyar Nemzeti Bank honlapjának adatai.

2018-ban meghatározó volt a dél-koreai befektetések dominanciája. A dél-koreai FDI-állomány részesedése közel kétharmados volt, míg a japáné 27 , addig a „későn jövő" kínaié több mint 7\%-os. Érdekes megvizsgálnunk a visegrádi országoknak az EU-ban befektetett összes ázsiai FDI-ből való részesedését: a dél-koreai egyharmada, a japán és a kínai mindössze csak 1,4-1,5\%-a érkezett a visegrádi országokba (1. táblázat).

A kínai FDI az EU-ban 2010-től 2016-ig több mint 17-szeresére nőtt. Bár különösen az elmúlt évtizedben Kelet-Közép-Európa felértékelódött a régióba érkező növekvő kínai befektetések következtében, de a régió csak kis részt képvisel az EUba érkező ázsiai FDI-n belül. 2017-ben a kínai FDI egyharmada érkezett az EU-ba, de azon belül csak 2,7\%-a jött a kelet- és délkelet-európai régióba. A kínai befektetések jelentôsége a régión belül is differenciált, bizonyos országokban például a kínai FDI GDP-arányos részesedése jelentősen eltér (például Boszniában 12, Csehországban $2 \%$ ).

Számos tanulmány vizsgálta a feltörekvő országok multinacionális vállalati befektetőinek motivációit és tőkebefektetési stratégiáit. Az eltérő tulajdonosi struktúrából, üzleti kultúrából és vállalatirányítási rendszerből adódó sajátosságok miatt a származási országgal kapcsolatos tényezôk jelentősen befolyásolhatják e vállalatok eltérő motivációt és stratégiáit (Filatotchev et al. 2007, Wang et al. 2009). Az FDI-nek a célországra gyakorolt hatását is csak ezeken - az eltérő motivációs sajátosságokon és expanziós stratégiákon - keresztül tudjuk megragadni (Sass et al. 2019). Újabb kutatás tárgyát képezheti a régióba érkező tradicionális ázsiai és a „későn jövő” kínai tőke specifikus telephelyválasztási motivációinak feltárása is.

Területi Statisztika, 2021, 61(1): 105-130; DOI: 10.15196/TS610105 
Cuervo-Cazurra $(2007,2008)$ a fejlődő országok multinacionális vállalatait úgy osztályozta, mint amelyek célja a külföldi tulajdonosi előnyök megszerzése, valamint a hazai piacon megszerzett előnyök külföldi kiaknázása. A hagyományos nemzetközi gazdaságtani elméletek nem alkalmazhatók például az ázsiai feltörekvő piaci befektetők esetében, mivel - ellentétben a nyugati világcégekkel - a fejlődő országok vállalatai esetében a nem hagyományos versenyelőnyök megszerzése motiválja a befektetéseket, hanem a versenyhátrányok leküzdése céljából hajtanak végre ilyen beruházásokat (Ramamurti 2012). Child és Rodrigues (2005) Kína esetén kimutatta, hogy a fó befektetési motiváció a külföldi technológia és a márkák megszerzése volt.

Míg a fejlett gazdaságokban megvalósított vállalatfelvásárlások, illetve külföldi leányvállalatok alapítása révén stratégiai előnyökhöz, addig a technológia és a képzett munkaerő megszerzésével jelentős erőforrásokhoz juttatják az anyavállalatot (Ramamurti-Singh 2009). Más szerzők inkább arra összpontosítottak, hogy a feltörekvő multinacionális vállalatok megbirkóznak a külföldi tulajdonszerzés felelősségével (Zaheer 1995, Luo-Tung 2007).

A Dunning-féle OLI-paradigma (1988) nem teljesen alkalmas a feltörekvő országok vállalatai nemzetköziesedésének leírására. Ugyanis ezek a „későn jövő” befektetők általában nem rendelkeznek olyan jelentős tulajdonosi előnyökkel, mint fejlettebb társaik, s külföldi terjeszkedésüket is részben ezen előnyök megszerzése motiválja (Mathews 2006, Contessi-El-Ghazaly 2010, Antalóczy-Sass 2014, GálJuhász 2016, Sass et al. 2012, Sass et al. 2019). A szakirodalom kiemeli, hogy az FDI nemcsak a cél-, hanem a befektető ország gazdaságára is hatást gyakorol, például az export, a termelési szerkezet, a fizetési mérleg, a technológia, a tudás, a gazdaságpolitika alakulása területén (Kokko 2006, Sass et al. 2019).

Fung és szerzôtársai (2009) a kínai, japán, dél-koreai és tajvani FDI-kiáramlás stratégiai motivációiról megállapították, hogy a természeti erőforrások fontossága míg részben érvényes Japán (élelmiszer és fémipar) és Dél-Korea (élelmiszeripar) vonatkozásában, addig a fejlett technológia megszerzésének szerepe Tajvan esetében volt meghatározó. Japánban és Kelet-Ázsia újonnan iparosodott gazdaságaiban az FDI-ket elsősorban a „push” tényezők generálják: a felértékelődött devizák, folyófizetésimérleg-többletek, munkaeróhiány és magas működési költségek, illetve a kisebb hazai piacok (Sass et al. 2019).

A „későn jövő” kínai befektetők esetében azonban a „pull”tényezők domináltak, például a legfontosabb természeti erőforrásokkal való ellátottság biztosítása, a devizabevételek növelése, a célországok közötti kereskedelmi akadályok megkerülése, az új piacokra történő behatolás, illetve a fejlett technológia és menedzsmentgyakorlat megszerzése (Deng 2004, Szunomár 2018). Ez utóbbi a legfontosabb motiváció a kínaiak EU-n belüli expanziójában. Ez magyarázza azt is, hogy a kínai befektetéseknél a zöldmezős beruházások alulreprezentáltak a vállalatfelvásárlással szemben. Szunomár (2018) a kínai befektetések nem gazdasági motivációit is áttekintve megállapította, hogy az egyéb faktorok (tartózkodási jog, oktatás, adókedvezmények,

Területi Statisztika, 2021, 61(1): 105-130; DOI: 10.15196/TS610105 
szociális tényezők, politikai kapcsolatok) is meghatározóak, amelyek nem jellemzőek a nyugati befektetőkre.

Sass és szerzőtársai (2019) kimutatták, hogy Dél-Korea kivételével a többi ázsiai ország befektetéseit közvetítő országokon keresztül valósítja meg. Ennek következtében a végső befektető számbavétele alapján a kínai (és a japán) befektetések is nagyságrendekkel meghaladják a közvetlen befektetôk szerinti számbavételt. A fő́bb magyarázó okok között a befektető elrejtése, a jobb piacismeret, az adóoptimalizálás és -elkerülés, az anyaországbeli bürokratikus és szabályozási terhek elkerülése, az anyacég felvásárlásával megörökölt leányvállalatok regionális irányító szerepének újrapozicionálása, a kontinentális (EU) piac- és termelésszervezés céljából. A közvetítő országhoz való földrajzi közelség is fontos szempont.

\section{Az ázsiai (kínai, japán és dél-koreai) befektetők hatékonyság- kereső stratégiái}

A következőkben a kelet-közép-európai régióba érkező kínai, japán és dél-koreai befektetések motivációit elemezzük, különös tekintettel a hatékonyságkereső stratégiákra. A befektetôk által követett stratégiák időben és térben változhatnak, de a befektetéseket illetően kölcsönös a cél- és a befektető országok elkötelezettsége. Vélhetôen a közvetítő országokon keresztül megvalósított befektetés is közvetett módon hozzájárulhat e stratégiák hatékonyabb megvalósításához, mindenekelőtt a piacszerzéshez és a költségek optimalizálásához. Fontos szerepet játszik továbbá a termelékenységet jelentősen növelő erőforrás-kereső stratégiákban (technológiai tudás), ami a kínai befektetők esetében egyik fontos motivációja a rejtőzködésnek, azaz a közvetítő országokon keresztül történő befektetéseknek. Ismert sajátosság, hogy a fejlett országok multinacionális vállalatai jelentős tudással és technológiával rendelkeznek, hatékonyabban múködnek, mint a feltörekvő országok nagyvállalatai (Castellani-Zanfei 2006). A fejlett országok multinacionális vállalatainak az FDI-vel szemben az az elvárása, hogy a megvalósuló technológiai fejlesztések és a termelékenység növekedése révén, bizonyos feltételek teljesülése esetén az járuljon hozzá az egész gazdaság termelékenységének javulásához (Smeets 2008).

A kutatás alapvetően három kelet-ázsiai országra fókuszál, ugyanakkor Ázsiában számos további országot is meg lehetett volna említeni, mely aktív befektetô a visegrádi országokban. A választás mögött egyrészt a három befektető ország földrajzi és kulturális közelsége áll. Másrészt az, hogy a modernizáció ezekben az országokban eltérő időszakban indult. Japán a legkorábban modernizálódott, iparosodott, ami igaz a nemzetközi aktivitására, így az FDI-re is. Kína a „későn jövő” és a legaktívabb új befektető. A hasonló gondolkodásmód, az ugyanazon szektorban egymással konkuráló cégek, valamint a közös kapcsolódási pontok a történelem folyamán feltételezik, hogy a befektetési stratégiák sem térnek el jelentôsen egymástól. Egymásra utaltságuk ma már megkérdójelezhetetlen (Farkas 2013). Különösen igaz ez Japán és Kína kapcsolatára. A két ország rendkívül aktív kereskedelmi és beruházási kapcso-

Területi Statisztika, 2021, 61(1): 105-130; DOI: 10.15196/TS610105 
latokat tart fenn, annak ellenére, hogy politikai viszonyaik rendkívül eltérőek. Kína is hasonló utat jár be az iparosodás terén, mint évtizedekkel korábban Japán és DélKorea. Ez azért is volt lehetséges, mert a második világháború után Japán gazdasági sikerei modellként szolgáltak a másik két ázsiai országnak. Mindhárom ország meghatározó szerepet tölt be Ázsiában és a világon is, valamint Kelet-Ázsia a világ leggyorsabban fejlődő régiói közé tartozik.

Az ázsiai multinacionális vállalatok egyik legfontosabb befektetési motivációja a piacszerző stratégia mellett a hatékonyságkereső stratégia. E stratégián belül nemcsak az alacsonyabb munkaerőköltség, hanem a magasabb munkatermelékenység is meghatározó. Balasubramanyam és Forsans (2010) szerint az indiai FDI-ket leginkább a „pull” tényezők mozgatják, melyek célja, hogy a nem hatékony és nem termelékeny, illetve bürokratikus hazai piacokkal szemben ezeket a tényezőket a fejlett országokbeli befektetéseiken keresztül próbálják megszerezni. A fejlett üzleti szolgáltatások a fejlett országokban létrehozott külföldi leányvállalatokon keresztül történő nemzetköziesedésével növelhető csak tovább az ágazat termelékenysége és versenyképessége. A viszonylag alacsony hazai bérek, az ágazatban elért magasabb termelékenység a forrása az indiai vállalatok nyugati terjeszkedésének. Ezzel szemben a kínai FDI-k hátterét a bőségesen rendelkezésre álló olcsó tőke adja, és nyugati cégek felvásárlása esetén a hatékonyságkereső stratégia a legfontosabb motiváció (Mathews 2002a, b, 2006, Buckley et al. 2007).

A szakirodalom a közvetlen tôke és a termelékenység kapcsolatát csak a fejlett országok multinacionális vállalatai által közvetített technológiai és termelékenységi kisugárzásokon (spillovers) keresztül vizsgálja (Javorcik 2004, Castellani-Zanfei 2006). Ugyanakkor néhány tanulmány foglalkozik a fejlettebb országokban befektető feltörekvő ázsiai világcégek hatékonyságkereső, illetve a termelékenységet fontos telepítôtényezőnek tekintő beruházásaival.

Még kevesebben vizsgálták azt, hogy a Kelet-Közép-Európában befektető ázsiai vállalatok esetében mennyire meghatározó telepítőtényező az említett stratégia. Kivételt képez McCaleb és Szunomár (2017) tanulmánya, melyben mindhárom (Kína, Japán, Dél-Korea) általunk is vizsgált ország befektetéseit elemezték a kelet-középeurópai régióra vonatkozóan. Megállapították, hogy a domináns piacszerző magatartáson kívül felfedezhetőek a hatékonyságkereső stratégia jelei is. Ennek egyik hajtóereje az EU átlagánál alacsonyabb munkaerőköltség. Ugyanakkor a régión belül a befektetés nagysága eltér az egyes országok között. Hiába alacsonyabb az egy egységre jutó bérköltség, valamint kedvezőbbek az adózási feltételek Romániában és Bulgáriában, a legtöbb tőke mégis a visegrádi országokba áramlik be.

Hipotézisünk szerint a Dunning-féle eklektikus elméletben (2000) megfogalmazott különböző befektetői stratégiák egyike a hatékonyságkeresés, illetve az erőforrás-keresés. Az előbbi az alacsonyabb munkaerőköltség mellett a növekvő termelékenység révén is realizálható. Az utóbbiban kiemelik a vállalati tudás (technológia) termelékenységnövelő hatását, ami vonzóvá teszi az adott célországot a befektetők számára. A különböző stratégiák mentén múködő cégeknek más és más befektetői 
motivációi lehetnek egy adott országban. Ugyanakkor a befektető ország fejlettségi szintje, a befektető vállalatok érettsége is meghatározó az adott (hatékonyságkereső, erőforrás-kereső) stratégia kiválasztásában. A nagyobb termelékenység tehát mindkét stratégiában hozzájárulhat a tőkevonzó képességhez. Ugyanakkor a munkatermelékenység alakulásában az ágazati és a regionális (lokális) tényezôk is meghatározó szerepet játszanak a szerkezeti tényezőkhöz képest. A termelékenység alapvetően a technológiaintenzív ágazatokban nagyobb, s az ezeket befogadó - válságrezisztensebb - régiók az erőforrás-kereső ázsiai befektetések fő célpontjai (CsugányMáté 2013).

A következőkben a kínai, a japán és a dél-koreai befektetők stratégiáit és befektetői motivációit tekintjük át a szakirodalom segítségével.

\section{Kína}

Carril és Milgram (2016) a Spanyolországban meglévő kínai befektetéseket vizsgálták. A kutatás során 94 vállalattól gyűjtöttek be kérdőíveket. Számtalan motivációs faktor mellett az eredmények azt támasztották alá, hogy a kínaiak célja olyan menedzseri képességek elsajátítása, melynek segítségével növelhető a termelékenység. A hatékonyságkereső kínai befektetôk gyakran fektetnek be olyan fejlett országokba, mint Spanyolország, annak érdekében, hogy hozzájussanak a fejlett technológiához és magasan kvalifikált szakembereket alkalmazzanak.

Chen (2015) kínai állami és nem állami cégek külföldi befektetéseit elemezte tartományi szintû mintán. Vizsgálatából arra a következtetésre jutott, hogy a piacszerzés mellett a hatékonyságkeresés a legfontosabb befektetési motiváció. A Kínában meglévő élénk verseny és a gyorsan emelkedő gyártási költségek elősegíthetik a magasabb termelékenységet elérni szándékozó cégek tôkekivitelét. A szerző különbséget vélt felfedezni az állami és a helyi magáncégek befektetési motivációja között. Bizonyos tartományokban a vállalatoknak fontosabb a tulajdonosi előnyök érvényesítése, melynek során új gyártási technológiához, tudáshoz, menedzsment- és marketingismeretekhez, valamint nemzetközi üzleti hálózatokhoz férhetnek hozzá.

Ross (2015) az Afrikában megvalósult kínai befektetéseket vette górcső alá. Afrikában egyértelmúen az erőforrás-kereső beruházások vannak többségben, azonban a szerző arra figyelmeztet, hogy ezen országoknak diverzifikálniuk kellene gazdaságukat, és felkészülni arra a helyzetekre, amikor a kínai tőke már csak kisebb mértékben lesz jelen. A kínai befektetők kevés figyelmet fordítanak a célországokban meglévő munkaerő minőségére és a termelékenységre. Tarrósy (2019) a kínai geopolitikai térnyerés motivációit mutatja be a pragmatikus kínai külpolitika afrikai sikerein, elsősorban infrastrukturális beruházásain keresztül.

Li és szerzôtársai (2014) Kína thaiföldi befektetéseit elemezték. Thaiföldnek különleges szerepe van a kínai tőkebefektetésekben, mivel az ország mintegy kapuként szolgál mind az Délkelet-ázsiai Nemzetek Szövetségének (Association of Southeast Asian Nations - ASEAN) tagországai, mind a világ felé. Előzetesen azt feltételezték,

Területi Statisztika, 2021, 61(1): 105-130; DOI: 10.15196/TS610105 
hogy a befektetők elsősorban erőforrás-kereső magatartást tanúsítanak majd. Ugyanakkor a kínai befektetések motivációi egyre inkább diverzifikálódtak, és számottevően megnőtt a hatékonyságkereső, valamint a stratégiaielőny-szerző befektetők száma is. E jelenség lényegében a kínai külföldi tôkebefektetések fejlődését, a hatékonyságkereső beruházások irányába történő elmozdulását tükrözi.

Lv és szerzôtársai (2018) az Európában meglévő kínai befektetések mozgatórugóinak szektorális tanulmányozásából arra a következtetésre jutottak, hogy összefüggés van a Kínában meglévő egyes iparágak magas termelékenysége és a $\mathrm{K}+\mathrm{F}$-be történő külföldi tôkkekihelyezés között. A célországban a $\mathrm{K}+\mathrm{F}$-intenzív szektorok több kínai $\mathrm{K}+\mathrm{F}$-indíttatású tôkét vonzanak. Továbbá a célországban lévő high-tech tevékenység releváns szempontnak bizonyult az innovációban érdekelt kínai befektetők számára. Minél jelentôsebb a célországban lévő $\mathrm{K}+\mathrm{F}$, valamint termelékenység, annál jelentősebbek az ilyen irányú befektetések. A szerzők végső soron megállapítják, hogy a kínai beruházókat sokkal inkább motiválja az EU-ban meglévő technológia és know-how, mint maga a piac. A kínai befektetések jelentős növekedése és az olyan érzékeny ágazatokba történő beruházások, mint az energia és a technológia, számos EU-tagországot óvatosságra intett a kínai expanzióval kapcsolatosan, már a COVID-válság előtti években is.

Sass (2018) a kínai FDI-k kelet-közép-európai vizsgálatairól megállapítja, hogy Magyarország relatíve fontos célpont az EU-n belül a kínai tőke számára. Lakosságszámához vagy gazdasági erejéhez (GDP-jéhez) viszonyítva hazánk a kínai tőke fontos európai fogadó országai közé tartozik. A magyarországi kínai projektek jellemzői hasonlítanak a kínai FDI szakirodalomban bemutatott általános sajátosságaihoz. A kínai állam kiemelkedő szerepe mind tulajdonosként, mind a gazdaság szervezésében rányomja a bélyegét a kínai multinacionális vállalatok versenyelônyeire (stratégiaieszköz-keresés, hatékonyságkeresés), valamint viselkedésére és jellemzőire is. Ezért - más fogadó országok tapasztalatai alapján - a fejlett országokból származó befektetésekhez hasonlítva kockázatosabbnak tekinthetők.

A Magyar Kína-Kutatásért Alapítvány (2011) tanulmánya szerint a kínaiak kevésbé a zöldmezős beruházásokban, inkább a meglévő nyugat-európai vállalatok felvásárlásában vagy fúziókban gondolkodnak. A kínai befektetéseknek egyik alapfeltétele a magyar munkaerő képzettsége. A kínai multinacionális vállalatok körében is egyre általánosabb az a tendencia, hogy megfelelő felsőoktatási képesítéssel és nemzetközi tapasztalattal rendelkező hazai, illetve kínai munkatársakat alkalmaznak, éppen a tudásátadási és munkaszervezési szinergiák megteremtése céljából.

\section{Japán}

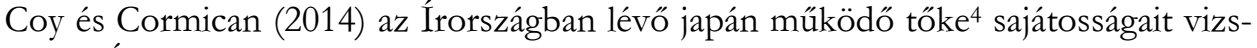
gálták. Írországban elsősorban az amerikai befektetések dominálnak, a többi országból érkező tôkét a szakirodalomban kevés figyelem övezi. Japán a világ egyik legna-

${ }^{4}$ A tanulmányban a közvetlen tőke és a működő tőke egymás szinonimái.

Területi Statisztika, 2021, 61(1): 105-130; DOI: 10.15196/TS610105 
gyobb befektetőjének számít, de Írországban a japán befektetők kisebb részarányt képviselnek, a munkaerő elenyésző részét alkalmazva. Megállapították, hogy a termelékenység vonzó tényező a japánok számára, akár olyan áron is, hogy többet fizetnek a munkaerőért. Következésképpen a bérköltségek szerepét is felülírja a hatékonyságkeresés, ugyanakkor a bércsökkenés további FDI-beáramlást generálhat.

Egy Lengyelországról készült jelentésből az derül ki, hogy a japán gyártóvállalatok gyakran helyezik oda tőkéjüket a gazdasági stabilitás, az alacsony bérek és a magas termelékenyég miatt (KPMG 2014). Ennek eredményeként a Lengyelországban található japán gyárak száma öt éven belül a másfélszeresére nőtt, míg NyugatEurópában a tevékenységük visszaszorulóban van. Ma már Lengyelország az öt legnagyobb japán gyáregységet magában foglaló európai ország között található. Az egy dolgozóra jutó kibocsátás tekintetében az ország kiemelt helyet foglal el a keletközép-európai régión belül.

A Polish Investment \& Trade Agency - Kochanski \& Partners (2019) közös jelentése szintén a Lengyelországban meglévő japán befektetéseket elemezte. Lényegében az alacsony bérköltségű lengyel munkaerőt tekintik az egyik legfontosabb vonzótényezőnek ahhoz, hogy egyre több japán vállalat helyezze ki a tevékenységét szolgáltató központokba. A külföldi vállalatokhoz tartozó mintegy 1200 osztott szolgáltató központ jelenleg is 300 ezer főt foglalkoztat Lengyelországban, így az üzleti szolgáltatások koncentrációja itt a legnagyobb Kelet-Közép-Európában. Az alacsony költségű és jól képzett munkaerő mindenképpen elősegíti az FDIbeáramlást az országba.

Afrikáról írott elemzésükben ${ }^{5}$ Chrysostome és Lupton (2011) arra a következtetésre jutottak, hogy a hatékonyságkereső beruházások részei az egyik legdominánsabb japán befektetési stratégiának. A cél az alacsony bérköltségú, de képzett munkaerő megszerzése elsősorban olyan területeken, ahol alacsonyabb technológiai ellátottság mellett folyik a termelés. Ez általában a szegényebb régiókra jellemző, melyekben kevésbé specializált gyártási tevékenységet folytatnak.

\section{Dél-Korea}

Kim és szerzőtársai (2016) Dél-Korea kínai beruházásait vizsgálták. A 2008-ban bekövetkezett gazdasági válság előtt a dél-koreai cégek elsősorban az alacsony munkaerőköltséget keresték Kínában, így szándékozva versenyelőnyhöz jutni. A válság utáni időszakban a dél-koreai befektetések diverzifikálódtak. Míg a kedvező munkaerőköltséget kereső beruházások már elsősorban a szegényebb, alacsonyabb infrastruktúrával rendelkező belső területekre irányultak, addig a tengerparti területeken a piacszerzési stratégia volt a domináns. A dél-koreai befektetési stratégia változása egész Kínában megfigyelhető, mely az alacsony munkaerőköltséget előnyben részesítő befektetések arányának csökkenéséhez vezetett.

51062 cég körében végzett vizsgálat alapján.

Területi Statisztika, 2021, 61(1): 105-130; DOI: 10.15196/TS610105 
Kwak (2007) a dél-koreai múködő tőkéről készített jelentésében leszögezi, hogy a világ egyes pontjaitól függően eltérő stratégiákkal találkozhatunk. Az évrôl évre jelentősebb hatékonyságkereső beruházások elsősorban Kínában és más ázsiai országokban figyelhetők meg. A dél-koreai cégek különösen a munkaintenzív gyártóüzemekben realizálnak versenyelőnyt az alacsony munkaerőköltség révén. A dél-koreai befektetések motivációja sokoldalú, azonban az otthoni munkaerőköltség emelkedése az egyik legfontosabb „push” tényező mind a kis- és közép-, mind a nagyvállalati szektorban.

A dél-koreai cégek kelet-közép-európai tókekihelyezései esetében a legfontosabb stratégiai szempont a rendelkezésre álló alacsony költségú és jól képzett munkaerő (Alvis 2006). A munkaerőköltség mintegy fele a nyugat-európainak. A délkoreaiaknak egyszerúbb gyártóüzemeket létesíteniük a régióban, amivel megtakarítják a hazájukból vagy a Kínából történő szállitás költségeit és idejét.

Oh és Mah (2017) a dél-koreai befektetések vietnámi vonatkozásainak kutatása során azt figyelték meg, hogy Kínából a tôke egy része kezdett Vietnámba áttelepülni. E jelenség egyrészt a befektetésösztönző kormányzati politika, másrészt a növekvő kínai bérek és egyre az szigorúbb szabályozás következménye.

\section{A hatékonyságkereső stratégiák és a munkatermelékenység összefüggései a visegrádi országokban (empirikus elemzés)}

\section{Adatproblémák, módszertan és korrelációanalízis}

A szakirodalom áttekintése során megállapítottuk, hogy a feltörekvő ázsiai országok multinacionális vállalatainak meghatározó befektetési motivációja a piacszerzés mellett a hatékonyságkeresés. Következésképpen a fejlettebb országokban befektető feltörekvő ázsiai világcégek a termelékenységet fontos telepítőtényezőnek tekintik beruházásaik során. Ezért empirikus elemzéssel megvizsgáljuk, hogy a Kelet-KözépEurópába befektető ázsiai vállalatok esetében mennyire meghatározó telepítôtényező az említett stratégia, továbbá azt is, hogy van-e különbség a feltörekvő kínai és a fejlett országcsoportból származó japán és dél-koreai befektetôk telephelyválasztási stratégiái között.

Az ázsiai és általában az FDI-beáramlásról többféle adatbázis áll rendelkezésre. Jelen esetben Eurostat-adatbázis alapján végezzük el az elemzéseket, melynek előnyei a következőkben foglalhatók össze:

- megegyezik az MNB-adatokkal,

- átlátható és visszakövethető,

- a régió összes országára ugyanazt a módszertant alkalmazza,

- csak a közvetlenül a befektető országból érkezett befektetésekre koncentrál,

- az adatokat euróban tünteti fel,

- hiteles, a szakma által is elfogadott adatbázis,

- hozzáférhető.

Területi Statisztika, 2021, 61(1): 105-130; DOI: 10.15196/TS610105 
Egy másik lehetséges forrás a Gazdasági Együttmúködési és Fejlesztési Szervezet (Organisation for Economic Co-operation and Development - OECD) adatbázisa lett volna, melyben már szerepelnek a közvetítő országokon keresztül érkezett befektetések is. Az OECD lényegesen nagyobb ázsiai befektetett tőkét mutat ki, mint az MNB, illetve az Eurostat (Montvai 2016). Az adatbázisok között meghúzódó eltérések okairól Sass és szerzőtársai (2019) részletesen értekeztek. Ezeken túlmenően megemlíthetjük a kínai Kereskedelmi Minisztérium (Ministry of Commerce of the People's Republic of China - MOFCOM) adatbázisát, illetve egyéb, kisebb adatbázisokat is, azonban ezek használata több szempontból is akadályokba ütközik.

A kutatás során alapvetô probléma volt a megfigyelések alacsony száma. Ez a tény alapvetôen korlátozta a statisztikai módszerek kiválasztását. Kétváltozós korrelációanalízissel lehetővé vált a különböző országokból érkező tőkebefektetések és a makrogazdasági mutatók közötti kapcsolat vizsgálata. Az alaphipotézis szerint az ázsiai befektetések esetében a megfelelő termelékenységi szint hozzájárul a tôkevonzó képesség erôsítéséhez a régióban. A termelékenységi mutatók kiválasztása az ENSZ Kereskedelmi és Fejlesztési Konferenciájának (United Nations Conference on Trade and Development - UNCTAD) módszertanán alapul. Az UNCTAD (2012, 30. old.) jelentése az egységnyi termékre jutó munkaerőköltség (unit labour cost - ULC) és a munkatermelékenység alakulását emeli ki mint lehetséges mutatót, ami befolyásolhatja a külföldi befektetők döntéseit.

Az elemzésben a független változók az egyes célországokban meglévő termelékenységi mutatók voltak, míg függő változónak az ázsiai (kínai, japán, dél-koreai) FDI-állomány felelt meg. A kutatás eredményei csak korlátozottan hasonlíthatók össze. Korlátai közül mindenképpen meg kell említeni, hogy a külföldi működő tőkéről csak 2003 óta állnak rendelkezésre Eurostat-információk, és a rövid időtartam miatt azokból nehezen vonhatók le megalapozott következtetések.

Korrelációanalízissel kijelöltük azokat a független változókat, melyek befolyásolták az ázsiai FDI-beáramlást, azonban a módszer jellege miatt az ok-okozati kapcsolatok rejtve maradtak. A választott módszertan erősen függött a lehetőségektől, és a megfigyelések alacsony száma miatt kizárólag a korrelációanalízis, valamint a Granger-okság teszt volt szakmailag indokolt, melynek segítségével már lehetővé vált a kauzalitás feltárása.

A Granger-okság teszteredményei megmutatják, hogy X befolyásolja-e Y változó alakulását, vagy $\mathrm{Y}$ mennyire hat $\mathrm{X}$ változóra. Matematikailag mindkét eset fennállhat, de az eredményekkel kapcsolatban figyelembe kell venni a következőket: 1) A célországban meglévő makrogazdasági mutatók vonzóvá tesznek egy országot a befektetők szemében, így az egyik irány könnyen igazolható, azonban ennek fordítottja már érdekesebb kérdés. 2) A beáramló ázsiai tőke hozzájárulhat ugyan a termelékenység alakulásához, azonban méretük olyan csekély, hogy ez csak elméletileg értelmezhető.

Területi Statisztika, 2021, 61(1): 105-130; DOI: 10.15196/TS610105 
A nullhipotézis szerint X nem oka Y-nak (Rappai 2011). Ebben az esetben nincs szükség X vizsgálatára, mivel Y múltbeli értékei alapján jobb becslést kaphatunk.

$$
\begin{aligned}
& H_{0}: \operatorname{MSE}\left(\hat{y}_{t+1} \backslash y_{t} y_{t-1}, \ldots\right)=\operatorname{MSE}\left(\hat{y}_{t+1} \backslash y_{t}, y_{t-1}, \ldots x_{t}, x_{t-1}, \ldots\right) \\
& H_{1}: \operatorname{MSE}\left(\hat{y}_{t+1}\left\lfloor y_{t} y_{t-1}, \ldots\right)>\operatorname{MSE}\left(\hat{y}_{t+1}\left\lfloor y_{t}, y_{t-1}, \ldots x_{t}, x_{t-1}, \ldots\right)\right.\right.
\end{aligned}
$$

ahol MSE = átlagos négyzetes eltérés.

A késleltetett érték (lag) maximuma négy volt, azaz a vizsgálat az FDI-állomány és a különböző makrogazdasági mutatók okozati összefüggésében egy, két, három és négy évre kiterjedő késleltetéssel történt meg.

A korrelációanalízis eredményei, 2003-2017

2. táblázat

\begin{tabular}{|c|c|c|c|c|c|c|c|}
\hline \multirow{3}{*}{$\begin{array}{c}\text { Befektető } \\
\text { ország }\end{array}$} & \multirow{3}{*}{ Célország } & \multirow{2}{*}{\multicolumn{2}{|c|}{$\begin{array}{c}\begin{array}{c}\text { Egységnyi termékre } \\
\text { jutó munkaerőköltség } \\
\text { (ULC) }\end{array} \\
\end{array}$}} & \multicolumn{2}{|c|}{ Egy munkaórára } & \multicolumn{2}{|c|}{ Egy foglalkoztatottra } \\
\hline & & & & \multicolumn{4}{|c|}{ jutó munkatermelékenység } \\
\hline & & $\mathrm{R}^{2}$ & p-érték & $\mathrm{R}^{2}$ & p-érték & $\mathrm{R}^{2}$ & p-érték \\
\hline \multirow{4}{*}{ Kína } & Csehország & 0,39 & 0,01 & 0,39 & 0,01 & 0,40 & 0,01 \\
\hline & Lengyelország & 0,40 & 0,01 & 0,31 & 0,03 & 0,31 & 0,03 \\
\hline & Magyarország & 0,49 & 0,00 & 0,40 & 0,01 & 0,14 & 0,17 \\
\hline & Szlovákia & 0,65 & 0,00 & 0,58 & 0,00 & 0,59 & 0,00 \\
\hline \multirow{4}{*}{ Japán } & Csehország & 0,61 & 0,00 & 0,85 & 0,00 & 0,84 & 0,00 \\
\hline & Lengyelország & 0,20 & 0,10 & 0,14 & 0,18 & 0,13 & 0,19 \\
\hline & Magyarország & 0,53 & 0,00 & 0,44 & 0,01 & 0,36 & 0,02 \\
\hline & Szlovákia & 0,05 & 0,44 & 0,04 & 0,47 & 0,05 & 0,41 \\
\hline \multirow{4}{*}{ Dél-Korea } & Csehország & 0,87 & 0,00 & 0,76 & 0,00 & 0,74 & 0,00 \\
\hline & Lengyelország & 0,09 & 0,26 & 0,20 & 0,10 & 0,20 & 0,09 \\
\hline & Magyarország & 0,86 & 0,00 & 0,75 & 0,00 & 0,38 & 0,02 \\
\hline & Szlovákia & 0,91 & 0,00 & 0,96 & 0,00 & 0,94 & 0,00 \\
\hline
\end{tabular}

Correlation analysis results, 2003-2017

\section{A munkatermelékenység elemzése}

Az ULC elemzése azt mutatja, hogy alapvetően egy külföldi befektetőnek az kedvező, ha a bérszínvonal alacsony marad, miközben a kibocsátás értéke növekszik, ugyanakkor a nominál bérnövekedés nem feltétlenül jelent hátrányt, amennyiben a termelékenység fejlődése annál nagyobb mértékủ. Zsibók (2019) szerint az egy főre jutó kibocsátás és a GDP-értékek növekedése nem minden esetben jelez gazdasági fejlődést, hiszen csökkenő népességszám esetén változatlan GDP mellett is növekszik a munkatermelékenység. Továbbá az ULC nem veszi figyelembe a gazdaság szerkezetének átalakulását, valamint a technológiai fejlődést, így önmagában a termékek drágább elóállítása adott esetben indokolt lehet.

Az 1. ábra azt mutatja, hogy az ULC legnagyobb mértékben Magyarországon romlott, ami lényegében termelékenységcsökkenéshez vezetett. Ugyanakkor a 2010.

Területi Statisztika, 2021, 61(1): 105-130; DOI: 10.15196/TS610105 
évi bázisévhez viszonyítva a régió többi országában a mutató hasonlóan alakult. A vizsgált időszakban Magyarországon drágult a kibocsátás. Ettől függetlenül nem lehet egyértelmúen kijelenteni, hogy romlott az ország versenyképessége, mivel az további tényezőktôl is függ. Ugyanakkor megállapíthatjuk, hogy a termelékenység növekedését meghaladó magyar bérnövekedést leginkább a munkaerőhiány magyarázza.

1. ábra

Az egységnyi termékre jutó munkaerőköltség (ULC) alakulása (2010=100\%)

Unit labour cost (ULC) $(2010=100 \%)$

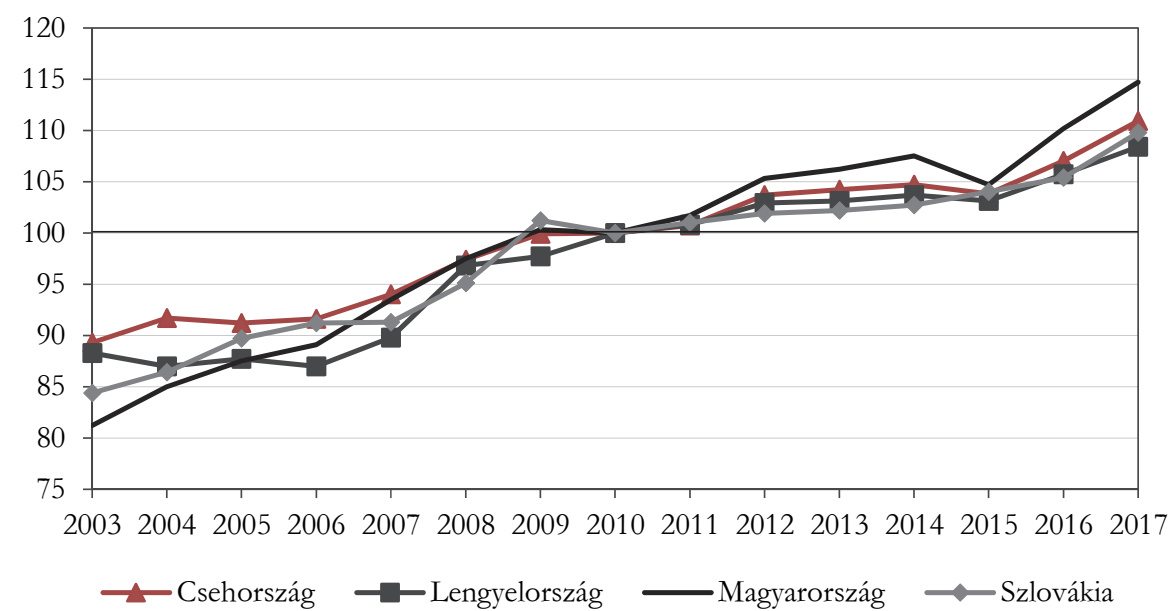

Forrás: saját szerkesztés az Eurostat honlapja alapján.

A korrelációanalízis eredményei azt mutatják, hogy mindhárom ázsiai állam befektetései összhangba hozhatók az ULC alakulásával. Kivételt csak Japán lengyelországi, illetve szlovákiai befektetései, valamint Dél-Korea lengyelországi beruházásai jelentenek. Ezekben az esetekben megállapítható, hogy a befektetők számára indifferens volt a független változó alakulása. A legszorosabb kapcsolat Szlovákiában figyelhető meg a dél-koreai befektetések esetében, de Csehországot és Magyarországot is rendkívül szoros kapcsolat jellemezte. A visegrádi országokon belül a legmagasabb termelékenységi mutatókkal rendelkező Csehországban és Szlovákiában a japán és a dél-koreai cégek esetében volt legnagyobb hatása a termelékenységnövekedésnek az FDI beáramlására. Ennek megfelelően a dél-koreai cégek számára a magas termelékenység egyértelmúen befektetési motiváció. A kínai befektetések esetében a munkatermelékenység és az FDI közötti kapcsolat erőssége közepes. A kínai FDI Szlovákia és Magyarország esetében reagált legerősebben a termelékenység javulására.

Az egy munkaórára jutó munkatermelékenység megmutatja, hogy a munkahelyen eltöltött idő alatt mennyit képes termelni egy munkavállaló. A régió országainak ezen a téren sem sikerült felzárkózniuk az EU és az OECD átlagához. Az egyes országok

Területi Statisztika, 2021, 61(1): 105-130; DOI: 10.15196/TS610105 
felzárkózási ütemében viszonylag jelentősek a különbségek. Míg az egy munkaórára jutó munkatermelékenység Lengyelországban közel 20, addig Magyarországon csak 4\%-kal bővült 2010 óta. Lényegében a hazai adatok stagnálnak, miközben a másik három országban jelentősen javult az egy munkaórára vetített termelékenység (2. ábra).

Az egy munkaórára jutó munkatermelékenység alakulása $(2010=100 \%)$

Changes in labour productivity per hour $(2010=100 \%)$

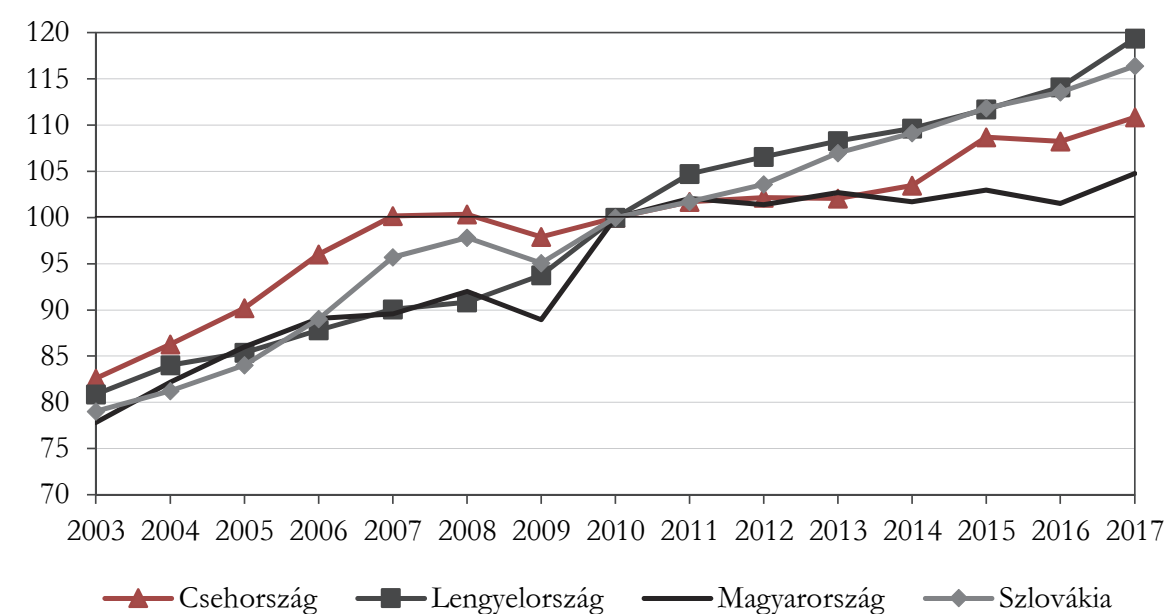

Forrás: saját szerkesztés az Eurostat honlapja alapján.

Egy foglalkoztatottra jutó munkatermelékenység és az országok rangsora az óránként mért mutatóhoz hasonlóan alakult. A 2010-es bázisévhez viszonyítva Lengyelország teljesített a legjobban, utána Szlovákia, Csehország és Magyarország következett (3. ábra). A magyar termelékenység e mutató szerint is szinte évtizedes változatlanságot tükröz, a többi visegrádi országban azonban tartós a növekedés. A 2008. évi mutató magasabb volt a bázisévinél, és a 2012. évi már visszaesésről árulkodott. A 2017. évi lényegében megegyezett a 2008. évivel, tehát gyakorlatilag ezen a téren nem volt semmilyen fejlődés. Lengyelország és Szlovákia termelékenységében nem volt viszszaesés, és Csehországban is csak egy átmeneti csökkenés volt 2012-2013-ban. Ettől függetlenül a másik három visegrádi ország termelékenysége már meghaladta a 2008. évi válság előtti szintet. Az egy foglalkoztatottra jutó munkatermelékenység a japán és a dél-koreai cégek esetében volt fontos motiváció, s leginkább a csehországi és a szlovákiai FDI-vel mutatott szoros korrelációt.

Megállapítható, hogy mindhárom munkatermelékenységi mutató esetében Magyarország a sereghajtó. Ennek okai sokrétűek lehetnek, az emelkedő bér, a verseny és az innovációk hiánya, valamint a nem megfelelő felnőttképzés, illetve a tartós munkaerőhiány mindenképpen valamilyen szinten indokolhatják a hazai munkater-

Területi Statisztika, 2021, 61(1): 105-130; DOI: 10.15196/TS610105 
melékenységi mutatók kedvezőtlen alakulását. Az elmúlt évtized gazdasági növekedését nem a termelékenység javulása magyarázza, hanem más egyéb (foglalkoztatásbővülés, EU-források) extenzív tényezők. Ha a munka és a tôke felhasználásának hatékonysága nem változik hosszú távon, akkor fennáll annak a veszélye, hogy az ázsiai és a többi külföldi befektetők visszafogják a beruházásaikat, esetleg áttelepítik egységeiket más országokba. A visegrádi országok tekintetében is elvárható lenne, hogy ne legyenek ekkora különbségek az egyes országok között. Amennyiben a cél az, hogy minél nagyobb volumenú ázsiai tőke érkezzen a régióba, úgy a döntéshozóknak különös figyelmet kellene szentelniük a termelékenység alakulására.

\section{Az egy foglalkoztatottra jutó munkatermelékenység alakulása $(2010=100 \%)$} Changes in labour productivity per employee $(2010=100 \%)$

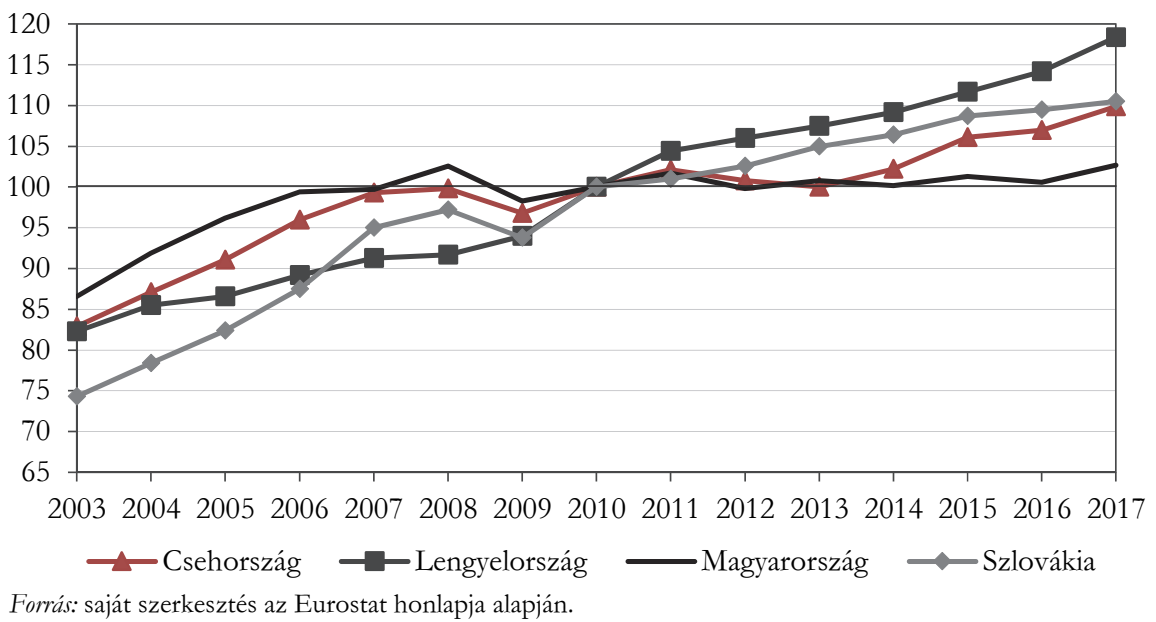

\section{Granger-okság teszt}

A korrelációanalízis mellett a Granger-okság teszt alkalmazása volt még szakmailag indokolt. Az előzőekben kimutattuk a kapcsolatok szorosságát, de az ok-okozati összefüggéseket már nem. A Granger-okság teszttel lehetôvé vált a kauzalitás feltárása, azonban ez a módszer csak a mutatók egy kis részénél volt alkalmazható. A Granger-okság teszteredményeit a 3. táblázatban foglaltuk össze.

A késleltetett érték (lag) maximuma négy volt, azaz a vizsgálat az FDI-állomány és a makrogazdasági mutatók okozati összefüggésében egy, két, három és négy évre kiterjedő késleltetéssel történt meg, melynek során egyirányú kapcsolatok rajzolódtak ki. 5\%-os szignifikanciaszint mellett főként az FDI befolyásolja a független változók (munkatermelékenység) alakulását, de bizonyos esetekben a lokális makrogazdasági mutatók hatottak a vizsgált ázsiai országok tőkebefektetéseire. Leginkább Japán esetében kaptunk érvényes Granger-okság teszteredményeket. A három befektető ország közül Japán és Dél-Korea egyértelműen - a fejlett országok multina-

Területi Statisztika, 2021, 61(1): 105-130; DOI: 10.15196/TS610105 
cionális vállalataihoz hasonlóan - maga is egyfajta technológiatranszfert valósít meg, ami egy magasabb termelékenységi szintet indukál. Természetesen nem lehet kijelenteni, hogy kizárólagosan az ázsiai FDI befolyásolta az ULC mutató, valamint az egy munkaórára és az egy foglalkoztatottra jutó munkatermelékenység alakulását, azonban a teszteredmények megmutatták, hogy van-e valamilyen kapcsolat a változók között.

3. táblázat

A Granger-okság teszteredményei, 2003-2017

Results of the Granger causality, 2003-2017

\begin{tabular}{c|l|c|c|c|c|c}
\hline $\begin{array}{c}\text { Befektetó } \\
\text { ország }\end{array}$ & \multicolumn{1}{|c|}{ Célország } & lag & p-érték & Reláció & Ok & Okozat \\
\hline \multirow{4}{*}{ Kína } & Magyarország & 4 & 0,05 & Egyirányú & $\begin{array}{c}\text { Egy munkaórára } \\
\text { jutó termelékenység }\end{array}$ & FDI \\
\cline { 2 - 7 } & Magyarország & 1 & 0,05 & Egyirányú & $\begin{array}{c}\text { Egy munkaórára } \\
\text { jutó termelékenység }\end{array}$ & FDI \\
\cline { 2 - 7 } & Lengyelország & 2 & 0,04 & Egyirányú & $\begin{array}{c}\text { Egy munkaórára } \\
\text { jutó termelékenység }\end{array}$ & FDI \\
\hline \multirow{5}{*}{ Japán } & Magyarország & 4 & 0,03 & Egyirányú & FDI & ULC \\
\cline { 2 - 7 } & Magyarország & 1 & 0,02 & Egyirányú & FDI & ULC \\
\cline { 2 - 7 } & Magyarország & 4 & 0,01 & Egyirányú & $\begin{array}{c}\text { Egy munkaórára } \\
\text { jutó termelékenység }\end{array}$ & FDI \\
\cline { 2 - 7 } & Szlovákia & 2 & 0,03 & Egyirányú & FDI & ULC \\
\cline { 2 - 7 } & Szlovákia & 1 & 0,02 & Egyirányú & FDI & $\begin{array}{c}\text { Egy munkaórára } \\
\text { jutó termelékenység }\end{array}$ \\
\cline { 2 - 7 } & Szlovákia & 1 & 0,03 & Egyirányú & FDI & $\begin{array}{l}\text { Egy foglalkoztatottra } \\
\text { jutó termelékenység }\end{array}$ \\
\hline \multirow{2}{*}{ Dél-Korea } & Lengyelország & 2 & 0,05 & Egyirányú & FDI & $\begin{array}{c}\text { Egy munkaórára } \\
\text { jutó termelékenység }\end{array}$ \\
\cline { 2 - 7 } & Lengyelország & 3 & 0,04 & Egyirányú & FDI & $\begin{array}{l}\text { Egy foglalkoztatottra } \\
\text { jutó termelékenység }\end{array}$ \\
\hline
\end{tabular}

A Granger-okság teszteredményeiből világosan kirajzolódik a fejlett, illetve a feltörekvő ázsiai országokból érkező befektetők stratégiáiban meglévő különbség. Míg a japán és a dél-koreai befektetések pozitívan hatnak a kelet-közép-európai célországok termelékenységi szintjére, addig a kínai befektetéseket a célországok magasabb termelékenységi mutatói indukálják (okozzák).

A teszteredmények tovább erősítik az egyes makrogazdasági mutatók és az ázsiai befektetések közötti pozitív kapcsolatot. Különösen azokban az országokban, melyekben bizonyos mutatók - a Granger-okság teszteredményei alapján - befolyásolják az ázsiai FDI-beáramlást, ott az adott kormányzatnak érdemes lenne különböző célirányos fejlesztésekkel vonzóbbá tennie a gazdasági környezetet a tôkebefektetések számára.

Területi Statisztika, 2021, 61(1): 105-130; DOI: 10.15196/TS610105 


\section{Összefoglalás}

A 2008. évi válság jelentette fordulópont erősítette az ázsiai befektetők érdeklődését az EU és szűkebben a kelet-közép-európai régió iránt, illetve a régió országai is igyekeztek az egyoldalú nyugat-európai tőkefüggőségüket diverzifikálni, és tőkeéhségüket az ázsiai, mindenekelőtt az expanzív kínai befektetők révén kielégíteni. A japán és a dél-koreai tôke korábban sem volt ismeretlen a régióban, azonban a kínai beruházások csak a válságot követően számítanak egyre jelentősebbnek.

A tanulmány arra a kérdésre keresett választ, hogy az ázsiai befektetőket mennyire motiválják a célországokban meglévő termelékenységi teljesítmények, azaz, hogy az ázsiai befektetések függnek-e az ottani termelékenységi mutatók alakulásától, a termelékenységben megmutatkozó országok közötti különbségektől.

A szakirodalom alapján megállapítottuk, hogy a hagyományos nemzetközi gazdaságtani elméletek nem alkalmazhatók például az ázsiai feltörekvő piaci befektetők esetében, mivel ellentétben a nyugati és a fejlett ázsiai országok multinacionális vállalataival, a fejlődő országok vállalatai esetében nem a hagyományos versenyelőnyök megszerzése motiválja a befektetéseiket, hanem versenyhátrányaik leküzdése miatt hajtanak végre - elsősorban stratégiaieszköz-kereső - beruházásokat. A kínai befektetők elsődleges motivációja a piacszerzés mellett a hatékonyságkeresés és az erőforrás-keresés, amelynek révén a fejlett gazdaságokban megvalósított vállalatfelvásárlásaikkal stratégiai előnyökre tesznek szert. A technológia és a képzett munkaerô megszerzésével jelentős erőforrásokhoz, illetve ezek révén magasabb termelékenységnövekedéshez juttatják a befektető vállalatot. Ennek bizonyítására empirikus vizsgálattal elemeztük az FDI és a termelékenység kapcsolatát a fejlett és a feltörekvő ázsiai országok multinacionális vállalatai által követett telephelyválasztási stratégiákban.

Elemzésünk az ázsiai befektetők hatékonyságkereső preferenciáinak és a munkatermelékenységnek (három termelékenységi mutatójának) az összefüggéseit mutatta be a visegrádi országokban. Azt vizsgáltuk, hogy a Kelet-Közép-Európában befektető ázsiai vállalatok esetében mennyire meghatározó telepítőtényező az említett preferencia, továbbá azt is, hogy van-e különbség a feltörekvő kínai és a fejlett országcsoportból származó japán és dél-koreai befektetők telephelyválasztási stratégiái között. Empirikus vizsgálati eredményeink azt mutatták, hogy mindhárom ázsiai ország vállalati befektetéseinél meghatározó stratégiai szempont a munkatermelékenység alakulása. Lényegében Kína, Japán és Dél-Korea esetében is kimutatható, hogy a befektetési motivációkat meghatározza a régióban meglévő termelékenységi szint, de természetesen befektető országonként eltérő módon. A visegrádi országokon belül legmagasabb termelékenységi mutatókkal rendelkező Csehországban és Szlovákiában a japán és a dél-koreai cégek esetében volt legnagyobb vonzereje a termelékenység növekedésének az FDI-re. A kínai befektetések esetében azonban közepes a termelékenység és az FDI közötti korrelációs kapcsolat erôssége.

A Granger-okság teszttel igazoltuk a fejlett, illetve a feltörekvő ázsiai országokból érkező befektetők stratégiáiban meglévő különbséget. A japán és a dél-koreai vállalatok befektetései maguk is egyfajta technológiatranszfert valósítanak meg, ami

Területi Statisztika, 2021, 61(1): 105-130; DOI: 10.15196/TS610105 
egy magasabb termelékenységi szintet indukál. Esetükben az FDI hozzájárul a munkatermelékenység javulásához. Míg a japán és a dél-koreai befektetések pozitívan hatnak a kelet-közép-európai célországok termelékenységi szintjére, addig a kínai FDI-ket a célországok magasabb termelékenységi mutatói vonzzák (okozzák).

A visegrádi országok között megfigyelhetó termelékenységi különbségek megmutatkoznak a vizsgált munkatermelékenységi mutatók alakulásában. Mindhárom mutató esetében Magyarország a sereghajtó, ami jelentősen rontja az ország versenyképességét, és már középtávon is negatívan befolyásolhatja az ország tôkevonzó képességét.

\section{Köszönetnyilvánítás}

A tanulmány a K-135185 (A külföldi múködőtoóke mikro-, makrogazdasági és területi differenciáló hatásai a Visegrádi országokban) számú projekt keretében, a Nemzeti Kutatási Fejlesztési és Innovációs Alap támogatásával valósult meg.

\section{IRODALOM}

ALvIS, J. H. (2006): Developments on Korea's overseas foreign direct investments KEI Insight http://keia.org/sites/default/files/publications/december 2006.pdf (letöltve: 2020. május)

ANTALÓCZY, K.-SASS, M. (2014): Tükör által homályosan. A külföldi közvetlentőkebefektetések statisztikai adatainak tartalmáról Külgazdaság 58 (7-8): 30-57.

BALASUBRAMANYAM, V. N.-FORSANS, N. (2010): Internationalisation drivers of Indian firms Asia Business \& Management 9 (3): 319-340. https://doi.org/10.1057/abm.2010.14

BlomstrÖM, M.-KoKKO, A. (1998): Multinational corporations and spillovers Journal of Economic Surveys 12 (3): 247-277. https://doi.org/10.1111/1467-6419.00056

Buckley, P. J.-Clegg, L.-Cross, A.-Liu, X.-Voss, H.-Zheng, P. (2007): The determinants of Chinese outward foreign direct investment Journal of International Business Studies 38 (4): 499-518. https://doi.org/10.1057/palgrave.jibs.8400277

Carril, F.-Milgram, J. (2016): Chinese outward FDI in Spain. An analysis of the determinants at the firm level. In: XI INTECO Workshop on Economic Integration Castellón de la Plana, 24-25 November 2016. https://doi.org/10.13140/RG.2.1.3255.9526

CASTELlani, D.-ZANFeI, A. (2006). Multinational firms, innovation and productivity Edward Elgar Publishing, Cheltenham, United Kingdom.

CHEN, C. (2015): Determinants and motives of outward foreign direct investment by China's provincial firms Transnational Corporations 23 (1): 28. https://doi.org/10.18356/6ba5ab37-en

Child, J.-Rodrigues, S. B. (2005): The internationalization of Chinese firms. A case for theoretical extension? Management and Organization Review 1 (3): 381-410. https://doi.org/10.1111/j.1740-8784.2005.0020a.x

Területi Statisztika, 2021, 61(1): 105-130; DOI: 10.15196/TS610105 
Chrysostome, E. V.-Lupton, N. C. (2011): Characteristics and performance of Japanese Foreign Direct Investment in Africa International Journal of Economic Policy in Emerging Economies 4 (1): 54-77. https:/ /doi.org/10.1504/IJEPEE.2011.038873

Contessi, S.-EL-GHAZALY, H. (2010): Multinationals from emerging economies. Growing but little understood The Regional Economist Issue July: 16-17.

COY, R.-CORMiCAn, K. (2014): Determinants of foreign direct investment. An analysis of Japanese investment in Ireland using the Kanomodel Investment Management and Financial Innovations 11 (1): 8-17.

Cuervo-Cazurra, A. (2007): Sequence of value-added activities in the multinationalization of developing country firms Journal of International Management 13 (3): 258-277. https://doi.org/10.1016/j.intman.2007.05.009

Cuervo-Cazurra, A. (2008): The multinationalization of developing country MNEs. The case of multilatinas Journal of International Management 14 (2): 138-154. https://doi.org/10.1016/j.intman.2007.09.001

CsugÁNY, J.-MÁTÉ, D. (2013): A munkatermelékenységben bekövetkezett szektorális változások technológia-intenzív megközelítésben Terïleti Statisztikea 53 (4): 340-353.

Deng, P. (2004): Outward investment by Chinese MNCs. Motivations and implications Business Horizons 47 (3): 8-16. https:/ / doi.org/10.1016/S0007-6813(04)00023-0

DUNNING, J. H. (1981): Explaining the international direct investment position of countries. Towards a dynamic and developmental approach Weltwirtschaftliches Archiv 117: 30-64. https://doi.org/10.1007/BF02696577

Dunning, J. H. (1988): The Ecletic Paradigm of International Production. A Restatement and Possible Extensions Journal of International Business Studies 19 (1): 1-31. https://doi.org/10.1057/palgrave.jibs.8490372

DunNing, J. H. (1992): Multinational enterprises and the global economy Addison-Wesley, Wokingham, Berkshire, United Kingdom.

DuNNING, J. H. (2000): The eclectic paradigmas as an envelope for economic and business theories of MNE activity International Business Review 9 (2): 163-190. https://doi.org/10.1016/S0969-5931(99)00035-9

DunNing, J. H.-Lundan, S. M. (2008): Multinational enterprises and the elobal economy Second Edition, Edward Elgar, Cheltenham, United Kingdom.

FARKAS, I. (2013): Ázsia évszázada? Egy felemelkedő régió modernizációja és viszonyrendszerei Világtörténet 35 (2-3): 161-164.

Filatotchev, I.-Strange, R.-Piesse, J.-Lien, Y. (2007): FDI by firms from newly industrialised economies in emerging markets. Corporate governance, entrymode and location Journal of International Business Studies 38 (4): 556-572. https://doi.org/10.1057/palgrave.jibs.8400279

Fung, K. C.-GArCiA-Herrero, A.-SiU, A. (2009): A Comparative empirical examination of outward direct investment from four Asian economies. China, Japan, Republic of Korea and Taiwan Asian Development Review 26 (2): 86-101.

GÁL, Z. (2010): Pénzüigyi piacok a globális térben. A válság szabdalta pén zügyi tér Akadémiai Kiadó, Budapest.

GÁL, Z,-JUHÁSZ, B. (2016): A vállalatok nemzetköziesedésének vizsgálata Kelet-KözépEurópában makrogazdasági módszerekkel Vezetéstudomány 47 (8): 26-39.

Területi Statisztika, 2021, 61(1): 105-130; DOI: 10.15196/TS610105 
GÁL, Z.-SCHMIDT, A. (2017): Geoeconomics in Central and Eastern Europe. Implications of FDI. In: MunOz, J. M. (ed.): Advances in Geoeconomics pp. 76-93., Europa Economic Perspectives, Routledge Taylor \& Francis Group, London \& New York.

GÁL, Z. (2019): Az FDI szerepe a gazdasági növekedés és a beruházások területi differenciálódásában Magyarországon Közgazdasági Szemle 66 (6): 653-686. https://doi.org/10.18414/KSZ.2019.6.653

GORECZKY, P. (2017): Közvetlen külföldi tőkebefektetések a változó világban KKI-elemzések, E-2017/28, Külügyi és Külgazdasági Intézet, Budapest.

JAVORCIK, B. (2004): Does foreign direct investment increase the productivity of domestic firms? In search of spillovers through backward linkages American Economic Review 94 (3): 605-627.

Kalotay, K. (2004): Outward FDI from Central and Eastern European Countries Economics of Planning 37: 141-172. https://doi.org/10.1007/s10644-004-7506-Z

KALOTAY, K. (2010): Patterns of inward FDI in economies in transition Eastern Journal of European Studies 1 (2): 55-76.

KIM, J. Y.-DRIFFIELD, N.-TEMOURI, Y. (2016): The changing nature of South Korean FDI to China International Journal of Multinational Corporation Strategy 1 (3-4): 269-287. https://doi.org/10.1504/IJMCS.2016.081127

KokKO, A. (2006): The home country effects of FDI in developed economies. European Institute of Japanese Studies Working Paper No. 225., Stockholm School of Economics.

KPMG (2014): Poland's Positionas a Business Partner for Japan KPMG, Warsaw.

KWAK, J. S. (2007): Korean FDI. Investment strategies and corporate motivations for investing abroad CEPAL -Serie Desarrollo productivo No. 182, United Nations, Santiago, Chile.

Li, M.-Ruangkanjanases, A.-ChEN, C. (2014): China's foreign direct investment in Thailand. Current status and future prospects International Journal of Trade, Economics and Finance 5 (4): 296-304. https://doi.org/10.7763/IJTEF.2014.V5.387

LUCAS, R. (1990): Why doesn't capital flow from rich to poor countries? American Economic Review 80 (2): 92-96.

LUO, Y.-TuNG, R. L. (2007): International expansion of emerging market enterprises. A springboard perspective Journal of International Business Studies 38 (4): 481-498. https://doi.org/10.1057/palgrave.jibs.8400275

Lv, P.-BArbieri, E.-Spigarelli, F.-Curran, L. (2018): An industry-based view of FDI exploring the motivations for Chinese OFDI in Europe across industries. In: $\sigma^{\text {th }}$ Copenhagen conference on ,emerging multinationals". Outward investment from emerging economies 11-12 October 2018, Copenhagen, Denmark.

MAgYAR KÍNA-KutATÁSÉRT AlAPÍTVÁNy (2011): Kinai munkaadók és munkavállalók Magyarországon Foglalkoztatási Hivatal, Budapest.

Mathews, J. A. (2002a): Dragon multinational. A new model of global growth Oxford University Press, Oxford.

Mathews, J. A. (2002b): Competitive advantages of the latecomer firm: A resource-based account of industrial catch-up strategies Asia Pacific Journal of Management 19 (4): 467-488. https://doi.org/10.1023/A:1020586223665

Területi Statisztika, 2021, 61(1): 105-130; DOI: 10.15196/TS610105 
Mathews, J. A. (2006): Strategizing, disequilibrium, and profit Stanford University Press, Stanford, California, USA.

McCAleb, A.-Szunomár, Á. (2017): Chinese foreign direct investment in central and eastern Europe. An institutional perspective. In: DrAHOKOUPIL, J. (ed.): Chinese investment in Europe. Corporate strategies and labour relations pp. 121-140., European Trade Union Institute, Brussels.

Montvai, B. (2016): Towards to interpretable FDI data in external statistics. Filtering distortions arising from globalisation from data of multinational enterprises. Practice of the Central Bank of Hungary. In: Conference of European statistics stakeholders Presentation, 20-21 October 2016, Budapest.

NARUla, R.-Guimón, J. (2010): The investment development path in a globalised world. Implications for Eastern Europe Eastern Journal of European Studies 1 (2): 5-19.

Nölke, A.-Vliegenthart, A. (2009): Enlarging the varieties of capitalism. The emergence of dependent market economies in East Central Europe World Politics 61 (4): 670-702. https://doi.org/10.1017/S0043887109990098

OH, J. H.-MAH, J. S. (2017): The patterns of Korea's foreign direct investment in Vietnam Open Journal of Business and Management 5: 253-271.

Polish Investment \& Trade Agency-Kochanski \& Partners (2019): Poland. Land of rising opportunities Polish Investment \& Trade Agency - Kochanski \& Partners, Warsaw, Poland.

RAMAMURTI, R.-SINGH, J. V. (2009): Emerging multinationals in emmerging markets Cambridge University Press, New York.

RAMAMURTI, R. (2012): What is really different about emerging market multinationals? Global Strategy Journal 2 (1): 41-47. https://doi.org/10.1002/gsj.1025

RAPPAI, G. (2011): Okság a statisztikai modellekben Statisz̧tikai Szemle 89 (10-11): 1113-1129.

Ross, A. G. (2015): An empirical analysis of Chinese outward foreign direct investment in Africa Journal of Chinese Economic and Foreign Trade Studies 8 (1): 4-19. https://doi.org/10.1108/JCEFTS-12-2014-0025

SANTISO, J. (2007): The emergence of Latin multinationals Deutsche Bank Research, Frankfurt am Main.

SASS, M. (2018): Hol volt, hol nem volt... Kínai tőkebefektetések Magyarországon és KeletKözép-Európában Külgazdaság 62 (11-12): 3-31.

SASS, M.-GuBIK, A.-ÉLTETŐ, A. (2012): Emerging multinationals and the role of virtual indirect investors. The case of Hungary Eastern European Economics 50 (2): 41-58. https://doi.org/10.2753/EEE0012-8775500203

SASS, M.-GuBIK, A.-SZUNOMÁR, Á. (2019): Ázsiai tőkebefektetések Magyarországon. Miért érkeznek gyakran közvetítő országokon keresztül? Statisztikai Szemle 97 (11): 1050-1070. http://doi.org/10.20311/stat2019.11.hu1050

SASS, M.-VLČKOVÁ, J. (2019): Just look behind the data! Czech and Hungarian outward foreign direct investment and multinationals Acta Oeconomica 69 (S2): 73-105. https://doi.org/10.1556/032.2019.69.S2.4

SMEETS, R. (2008): Collecting the pieces of the FDI knowledge spillovers puzzle World Bank Research Observer 23 (2): 107-138. https://doi.org/10.1093/wbro/lkn003

Területi Statisztika, 2021, 61(1): 105-130; DOI: 10.15196/TS610105 
SzunOmÁr, Á. (2018): Pull factors for Chinese FDI in East Central Europe Working Paper No. 249. Institute of World Economics, Centre for Economic and Regional Studies, Hungarian Academy of Sciences, Budapest.

SZUNOMÁR, Á.-MCCALEB, A. (2018): Chinese and other East Asian foreign direct investment in Central and Eastern Europe. Motives, Location Choices and Employment Approaches CESifo Forum 19 (4): 9-14.

TARrósy, I. (2019): A kínai „Övezet és Út Kezdeményezés” és Kelet-Afrika: geopolitikai térnyerés, infrastruktúra, függőség Területi Statisztika 59 (6): 669-692. http:/ / doi.org/10.15196/TS590604

UNCTAD (2012): World investment report United Nations, New York \& Geneva.

UNCTAD (2018): World investment report United Nations, New York \& Geneva.

VARGA, GY. (2018): Az Európán kívüli világból érkező külföldi működőtőke a visegrádi országokban Földrajzi Közlemények 142 (2): 110-121.

WANG, C.-CLEGG, J.-KAFOUROS, M. (2009): Country-of-origin effects of foreign direct investment. An industry level analysis Management International Review 49 (2): 179-198. http://doi.org/10.1007/s11575-008-0135-4

ZAHEER, S. (1995): Overcoming the liability of foreignness Academy of Management Journal 38 (2): 341-363. https://doi.org/10.5465/256683

ZsıBÓK, Zs. (2019): Minden marad a régiben? Regionalizált növekedési pályák Magyarországon Területi Statiştika 59 (3): 247-272. https://doi.org/10.15196/TS590301

HONLAPOK

EUROSTAT: Statistics http://epp.eurostat.ec.europa.eu/portal/page/portal/eurostat/home/ KÖZPONTI STATISZTIKAI HIVATAL: STADAT http://www.ksh.hu/stadat MAGYAR NEMZETI BANK: Statisztika https://www.mnb.hu/

NATIONAL BANK OF POLAND: Statistics https://www.nbp.pl/homen.aspx?f=/srodeken.htm NATIONAL BANK OF SLOVAKIA: Statistics https://nbs.sk/en/home

NATiOnAl BAnK Of The CZECH RepubliC: Statistics https://www.cnb.cz/en/

OECD: Statistics https://data.oecd.org 